\title{
121
}

\section{Remote sensing application in the conservation and management of coastal bio resources of the Palk Bay, Southeast coast of India}

\author{
R. Sridhar', T. Thangaradjou ${ }^{1}$ and L. Kannan ${ }^{2}$ \\ ${ }^{1}$ Centre of Advanced Study in Marine Biology, Annamalai University, Tamil Nadu, India \\ ${ }^{2}$ Thiruvalluvar University, Fort campus, Vellore, Tamil Nadu, India
}

\begin{abstract}
Various resources of the Palk Bay, Southeast coast of India viz. coral reefs, reef vegetation, dense seagrass beds, sparse seagrass beds, dense mangroves and sparse mangroves were classified through visual interpretation and digital image processing method using IRS-LISS - III (1996, 2000, 2002 \& 2004 ) satellite data. The resource maps were generated and reclassified after intensive ground truth verifications. The Palk Bay has shown an areal extent of 286.95 ha of reef area during 2004 , which is 177.54 ha lesser than that of the reef area of 1996 . The reef vegetation composed mainly of seaweeds, has gained over 29.44 ha and sand over reef area also has increased alarmingly i.e. 120.34 ha during the same period. The study has revealed the reduction of dense seagrass beds by 785.5 ha between 1996 and 2004 while the sparse seagrass beds have gained 513.68 ha during this period. The sparse mangrove cover area has increased to about 36.45 ha and there is also a 2.99 ha increase in the dense mangrove cover. Various reasons for the changes have been identified and based on which suitable plans have been suggested for the effective conservation and management of the important bio-resources of the Palk Bay.
\end{abstract}

